The Current Outlook in Church History By Williston Walker 



\section{THE CURRENT OUTLOOK IN CHURCH HISTORY}

By Williston Walker, Professor of Church History, YALE UNIVERSITY

(The Presidential Address, Read December 26, I9o7)

$\mathrm{O}^{\mathrm{NE}}$ of the duties of the office of President of this Society, to which you did me the honor to elect me for the year that has just closed, is to give an annual address. Its theme is, fortunately for the speaker, almost of necessity prescribed by the purposes of the Society and the nature of the office to which your kindness has chosen me, and he deems it, therefore, no less his duty than his privilege to bring before you in rapid survey, and in brief and inadequate outline, indeed, the principal events of the year which has elapsed since the last meeting of this Society, in so far as they relate themselves to its purpose, viz., the cultivation of church history.

While the year that is just closing has been marked by a considerable number of occurrences of significance, and has brought its proportion of contributions to the discussion of historical questions, it has not been distinguished either by events, or by publications, of unusual importance. It may fairly be described as an average year in its relations to church history.

There have been, however, three commemorations of significant anniversaries which have taken place during the past year and deserve mention among its occurrences. The first of these was the Centenary Conference of Protest- 


\section{I8 The Current Outlook in Church History}

ant Missions in [6] ${ }^{x}$ China, held in Shanghai, in April and May, the occasion being the one hundredth anniversary of the beginnings of the work, in that great empire, of Robert Morrison. It was far, indeed, from being the centennial of Christian missions in the Chinese Empire, for Roman Catholic effort is greatly older; but for Protestant Christendom, the event was certainly one of significance; and the commemoration, involving, as it did, the gathering together of representatives of all Protestant Mission Boards at present at work in China, and the discussion not merely of the history but of the present problems of missions, was on a scale worthy of the importance of the anniversary. A second commemoration of significance was that held in Jamestown and Richmond by the Convention of the Protestant Episcopal Church in the United States, in October, in which the three hundredth anniversary of the introduction of the Church of England by the first settlers of Virginia was appropriately brought to mind. The third commemoration attached itself, also, to an event, though of comparatively minor importance, in the history of the same communion, when, on June 12th, the two hundredth anniversary of the establishment of the Episcopal Church in Connecticut was worthily observed in Stratford in that state.

Among English-speaking Protestants, the year which has just closed may be described as characterized by the increasing manifestation of the spirit of union. In Scotland, where the juncture effected in 1900 between the Free and the United churches was followed by the refusal of a few congregations of the Free Church to join in the new communion, and the remarkable legal decision by which the property of the old Free Church as a whole was assigned to them, the year has witnessed the successful inauguration of the work

\footnotetext{
'The figures in brackets give the pagination of the former edition of these Papers.
} 
of a parliamentary commission by which substantial justice will undoubtedly be done to all parties and reasonably equitable division of the properties involved is being effected, so that the union of these two great, closely-related bodies of Scottish Christians, though still involving some sacrifice, will not be accompanied by the embarrassing pecuniary losses which at one time threatened. In Canada, union efforts looking towards [7] the association of Congregationalists, Presbyterians, and Methodists are in a high degree of advancement, and in New Zealand similar attempts have been auspiciously inaugurated. In the United States, the Northern Branch of the Presbyterian Communion and the Cumberland Presbyterians met, on May 16th, in Columbus, Ohio, in one General Assembly; and though the union thus inaugurated still encounters a very considerable degree of dissent, and by no means commands the support of all churches, perhaps of not more than of two thirds of the Cumberland churches, it is important for what it has already achieved and what it promises as to the future. The year has witnessed extensive negotiations looking towards the affiliation in one religious denomination of Congregationalists, United Brethren, and Methodist Protestants: but, though this effort has elicited much discussion, it has yet led to no definite results, and its outcome is still somewhat problematical. A step of significance for the relations of the Episcopal Communion with other religious bodies was taken by the convention of the Episcopal Church at its session in Richmond, when Episcopal pulpits were opened, under certain restrictions, for the preaching of ministers of other communions - a privilege, expressive of Christian fellowship, of which use is already being made. A prime characteristic, therefore, of the year which is just closing, as of several previous years among English-speaking Protestant Christians, is the development of the spirit of interdenominational fellowship - a tendency which the next few years is likely to see increased rather than diminished. 


\section{The Current Outlook in Church History}

Outside of English-speaking Christendom, an event of some historic interest has been the separation, this autumn, of Church and State in the canton of Geneva. The historic territorial church which has been established since the Reformation, and upon which Calvin left permanent impress, has been disestablished by a small majority of the Genevan electors-a result which was the practically inevitable consequence of the multiplication in Geneva itself of adherents of other communions, primarily of that of Rome, and to some extent of the presence there of representatives of types of Protestantism other than that of the Establishment. Each canton of Switzerland has its [8] peculiar ecclesiastical constitution and its territorial church. The numbers, therefore, involved in this separation are not large, and the action taken involves no other canton; but, in view of the historic significance of the Genevan church, the event is one of considerable importance.

The most significant occurrences of the year relate themselves, as in several years past, to the great Roman Communion, and in that body the events of the year 1907 must make the period which is just closing a memorable epoch. A year ago the situation of the Catholic Church in France was the chief concern. The law for the separation of Church and State, enacted on December 9, 1905, went into effect upon its passage, and since that time the French Catholic Church has been disestablished; but practically it was not until about the time of our meeting last year, that is, until one year after the passage of this law, that its complete operation was effected. A year of grace was given, under the new statute, for the formation of new societies for the maintenance of worship, the so-called associations cultuelles. Its provisions for an inventory of religious property met with not a little popular opposition. The exclusion of the religious orders and congregations was accomplished with some considerable hardship, and the situation was much embittered by the refusal of the papacy to sanction the 


\section{The Current Outlook in Church History}

associations which the law provided for the maintenance of worship. That attitude of rejection assumed by the papacy has continued, its main motives being undoubtedly the refusal by the French government to consider the papacy as in any sense a party to an agreement affecting the interests of the Church within the bounds of France, and the insistence of that government that the status of the French Church is purely a national question, regarding which it declines to give the papacy a share in the negotiations. The result has been that the now disestablished Church of France has occupied a position of painful legal uncertainty for the past year; but, thanks to the good sense of the government in refusing to force an issue, no serious disturbances have taken place, and disestablishment has become an accomplished fact. Perhaps the most significant feature of the transaction, from [9] the point of view of the religious future of the French nation, is the comparatively small degree of internal disturbance by which the great separation has been accompanied. The Roman Catholic Church of France has found its situation one of distressing financial embarrassment; but not without its aspects of encouragement. The response of the laity to the new burdens laid upon them has not been so generous as to make the situation an easy one, but it has been, nevertheless, considerable. Public worship has been everywhere maintained, candidates for the priesthood have continued to present themselves in respectable, if in somewhat decreasing, numbers; and it seems to be only a question of a relatively brief time before the Roman Catholic communion in France will have adjusted itself, successfully, to its new position. Should there be a change in its irreconcilable attitude on the part of papacy, there can be no doubt that the adjustment would be speedily accomplished. The Protestants of France who, like their Roman Catholic fellow-Christians, share in the trials and disadvantges of disestablishment, are meeting their perplexities with courage and good sense. 
Of much greater significance than this question of disestablishment, which loomed so large a year ago, has been the completion, during the past year, of a process of separation in the intellectual attitude of two important sections of the Roman communion, which has been ripening for a considerable time. A movement for freer adjustment between Catholic doctrine and modern thought in science, history, and philosophy has undoubtedly been rapidly claiming adherents. It has found able champions during the past few years in such men as the late Professor Herman Schell of the University of Würzburg, and Freiherr Georg von Hertling of the University of Munich, in Germany; in the Abbe Loisy and Father Albert Houtin in France; and Father George Tyrrell in Great Britain. Some of these had already come under papal discipline. A movement to erect a monument to Professor Schell had already encountered papal opposition; but, in spite of these signs of disapproval, the religious world was hardly prepared for the publication by the "Holy Roman and Universal Inquisition," under [Io] papal authority, on July 3d, of the so-called Syllabus, "Lamentabili sane exitu," which was followed on September 8 th, by the now famous papal Encyclical, "Pascendi dominici gregis," or more appropriately, "De Modernistarum Doctrinis"; and, on November I8th, by a "Motu Proprio" regarding Biblical studies and enforcing the Encyclical.

In these lengthy and elaborate ecclesiastical pronunciamentos the positions of those Catholic scholars who would interpret their faith in the light of modern science, philosophy, and history, are denounced, and to a certain extent, undoubtedly, unfairly stated. Modernism is pronounced a "synthesis of all heresies," and a vigorous anti-modernistic campaign is ordered to be inaugurated with weapons that, to a Protestant at least, sound strangely mediæval. Modernists are to be removed from teaching positions, the clergy and laity are forbidden to read modernistic publications. A committee of examination and censorship is to be estab- 


\section{The Current Outlook in Church History}

lished in every diocese; no clergyman is to assume the direction of publications without his bishop's permission; ecclesiastical conventions shall meet but rarely, and they are not to discuss matters affecting the episcopate or the higher interests of the church, and a "Council of Vigilance" is to be founded in every diocese to combat modern errors.

It is probably true that this drastic action is largely the work of a faction in the Roman Church, and the actual authorship of the Encyclical has been traced with a considerable degree of certainty. But there can be no doubt, also, that it represents an earnest pastoral desire on the part of the present Pope, who feels himself charged, as might the rector of a country congregation in France or Italy, with the repression of what he deems errors springing up among his flock. It has, nevertheless, brought into prominence a controversy which is apparently irreconcilable in the Roman Church itself, between widely held conceptions of the modern world and those of the thirteenth century; and while we may regard the evident manifestation of this division in thought and the action of the papacy towards it, as the prime ecclesiastical event of the year 1907, he would be a rash prophet, in view of the history of the [II] Roman Church, who would venture to predict what the outcome may be.

Turning now to the literature of Church History during the present year, we are met with one important discovery, viz., that of the Treatise of Irenaus on the Apostolic Preaching. This long-lost work, in which Irenæus sets forth familiar doctrinal positions and which, therefore, enlarges but little, if at all, our knowledge of the second century, was discovered in Armenian translation, and was issued in German, under Harnack's auspices, by two Armenian scholars, Karapet Ter-Mekerttschian and Earwand Ter-Minassiantz (Leipzig, 1907). The excavations of Egypt have yielded, besides a document of great interest to Old Testament scholars, showing that an elaborate Jewish temple, with sacrifices 


\section{The Current Outlook in Church History}

and ritual worship, existed on the island of Elephantiné before the Persian conquest of Egypt, a fragment of a conversation between Christ and a Pharisee, probably a thirdcentury document, though I am not aware that it has yet been published.

The completion of the Jewish Encyclopedia, in 1906, has been followed, this year, by the publication of the first two volumes of the Catholic Encyclopedia (New York, 1907); and the third (Albert Hauck's) edition of the great Realencyklopädie für prot. Theologie und Kirche is now slowly nearing completion, having made progress from Stephen III to Urban II during the year. Several important encyclopedic undertakings are in progress in this country, of which the most significant is the extensive work based upon the Realencyklopädie, of which the Secretary of this Society is Editor. During the year the Pope has ordered a new edition of the Vulgate to be prepared by Benedictine scholars, which will probably involve the labor of perhaps a decade before it is ready for publication.

The year has not been especially fruitful in the publication of sources. The most conspicuous recent work of this sort now in full progress, belonging, indeed, so far as the publication of its initial volume is concerned, to 1906, is the new Regesta Pontificum Romanorum (Volume I, Italia, Rome and Berlin, 1906; Volume II, Latium, 1907), by Paul Fridolin Kehr, under the auspices of the Gottinger Gesellschaft der [12] Wissenschaften. This work, which will undoubtedly supersede Jaffé and other collections of papal documents, is arranged geographically; and the investigations which have thus far been made regarding Italy, which is the first region considered, have yielded no less than II 54 heretofore unpublished charters and documents.

The first volume of the monumental Corpus Schwenckfeldianorum has been issued under the editorship of Chester David Hartranft, long President of Hartford Theological Seminary (Leipzig, 1907). This work will make available 


\section{The Current Outlook in Church History}

for the student of the Reformation age a wealth of unpublished material by and relating to Kaspar Schwenckfeld von Ossig, and is a monument to the interest of the Schwenckfelder Church of America in its founder.

Students of Church History will note with interest that a survey of the recent literature of the subject, that promises to be permanent, has been begun in the November number of the French Revue Historique, which has hitherto been largely secular in tone, by Charles Guignebert of the University of Paris, whose Manuel d'histoire ancienne du Christianisme (Paris, 1906), has shown his mastery of the literature and present status of discussion of early Christian history. Professor Harnack has turned aside from his more usual field, and has followed his defense of the Lucan authorship of the third Gospel and of the Acts, of a year ago (Lucas der Arzt, Leipzig, 1906), with an attempted reconstruction of the Logia sources of the Gospels (Die Sprüche und Reden Jesu, Leipzig, 1907), which, though fundamental to Church History, belongs rather to the technical field of New Testament studies than to those considered by this Society. The same may be said of Prof. James Orr's The Virgin Birth of Christ (New York, 1907), which is the ablest argument for the conservative position, not merely regarding the doctrine that gives the title to the work but toward the New Testament generally, that has recently been published in English. A thorough discussion of all available information bearing on the Neronian persecution is that of E. Theodor Klette, Die Christenkatastrophe unter Nero (Tübingen, 1907), in which the statements of Tacitus are criticised [13] in the light of allusions in Clement, Melito, Tertullian, and other Christian writers.

An American scholar, Prof. Edgar J. Goodspeed, of the University of Chicago, has given us a useful concordance of the Apostolic Fathers, under the title Index Patristicus (Leipzig, 1907). Gnosticism has been subjected to a careful examination by a competent Italian investigator, Prof. 


\section{The Current Outlook in Church History}

E. Buonaiuti, Lo Gnosticismo: Storia d'antiche lotte religiose (Rome, 1907), who discredits the influence of Oriental religions in its origin, and believes that its importance in the development of doctrine has been exaggerated. A French student, P. Saintyves, under the title Les Saints, successeurs des Dieux (Paris, 1907), has issued a valuable amplification of the results already in part reached by Lucius in his important Die Anfänge des Heiligenkults, of 1904. Saintyves finds the two main sources of saint worship in the pre-Christian reverence paid to heroes and demigods, and the honors accorded to the dead, especially to martyrs. The combination of the two tendencies, in his view resulted in the Christian worship of the saints. A significant investigation of Chrysostom's influence in history, which the year has brought forth, is that of Christian Baur, Saint Jean Chrysostom et ses ceuvres dans l'histoire littéraire (Paris, 1907). Our own Prof. Warfield of Princeton has continued through the year his valuable studies of Augustine, in the Princeton Theological Review.

Turning now to the Middle Ages, the year has contributed a careful examination of the pseudo-Isidorian decretals, the work of P. Fournier, Etudes sur les fausses Décrétales (Louvain, 1907). Fournier agrees with Hinschius in dating the composition of these decretals between 847 and $85^{2}$, but shows good reasons for regarding their orgin as in the region of Tours and not that of Rheims; and also for believing that Pope Nicholas I, the earliest pope to make use of them, was not acquainted with the collection as a whole, but simply had a few of these forgeries before him. Our own American scholar, Prof. David S. Schaff, has published during the year (New York, 1907) the first part of the fifth volume, continuing his father's well-known History of the Christian Church, from [14] 1049 to 1294. Prof. Schaff has succeeded with remarkable skill in reproducing the spirit and method of his father's familiar and useful work. Perhaps the point to attract most immediately the 
reader of this volume is a vigorous defense of the traditional view of the influence of Peter the Hermit in the origin of the First Crusade, which had been so generally discredited since the labors of von Sybel. A French scholar, Louis Bréhier, in his L'Église et l'Orient au Moyen Age: Les Croisades (Paris, 1907), has published a good compendium of crusading history fully abreast of modern discussions but contributing very little that is new to the understanding of the movement or the age in which it took place. On the other hand, German patriotism has led A. Dammann in his Der Sieg Heinrichs IV in Kanossa (Braunschweig, 1907), into an attempt to show that Henry IV was not an humble suppliant before Hildebrand at Canossa but assertively and victoriously demanded the removal of the Pope's bann as king and prospective head of an army. A good study of the only Englishman who has ever occupied the papal throne is that of a young English scholar, J. D. Mackie, Pope Adrian IV (Oxford, 1907); and a German student, Anton Eitel, in his Der Kirchenstaat unter Klemens V (Berlin, 1907), has shown that this first of the Avignon popes, however lacking in some other qualities desirable in an occupant of his office, manifested a statesmanlike ability in his relations to Italy, for which previous historians had not given him credit.

The interest in Saint Francis and his times which is so markedly a feature of the present age has not resulted, during the past year, in works of prime importance. Father Paschal Robinson, in his short Introduction to Franciscan Studies (New York, 1907), has given an exceedingly useful little guide to the rapidly multiplying literature on this theme, and in his Golden Sayings of the Blessed Brother Giles of Assisi (Philadelphia, 1907) has made available in English the writings of an intimate companion of Francis, which illustrate the more spiritual aspects of the Franciscan movement. The Herbert Baxter Adams Prize for 1905, of our American Historical Association, was awarded to Dr. David S. Muzzey for his valuable study [ $\mathrm{r} 5$ ] of The Spiritual Franciscans (New 
York, 1907), in which he has discussed their story from the death of Saint Francis to the times of Pope John XXII.

American scholarship has long and deservedly been proud of the work of Mr. Henry C. Lea, and the year has witnessed the completion, by the publication of the third and fourth volumes (New York, 1907), of his painstaking and extensive History of the Inquisition of Spain, which must long continue to be regarded as an authority of prime importance on this theme. Mr. Lea has also issued in revised form, during the past year, his well-known History of Sacerdotal Celibacy (New York, 1907).

The perennial interest in the Reformation has been illustrated as usual, during the past year, its most significant result being the completion of Principal Thomas M. Lindsay's, History of the Reformation (Edinburgh and New York, I9067). Dr. Lindsay's work is at its best in its treatment of the Reformation in Germany, especially in its knowledge of the popular life and of the household type of piety in which he has shown that so much of the springs of the Lutheran movement are to be found. His second volume, treating of the Reformation outside of the land of its origin, is much more hasty in composition and much less satisfactory in proportionment and contains relatively little that is new. But the two volumes as a whole constitute the best history of the Reformation now available in English. Similar praise cannot be given to J. P: Whitney's The Reformation (London and New York, 1907) in W. H. Hutton's "Church Universal Series." The standpoint of the author is that of an Anglo-Catholic, and his treatment of his theme, from a scholarly point of view, does not compare with that of Dr. Lindsay. Dr. Preserved Smith, son of the well-known Old Testament scholar, in his Luther's Table Talk: A Critical Study (New York, 1907), has presented a valuable discussion of one of the important sources of our knowledge of the great Reformer; while August Lang of Halle, already distinguished for his significant studies regarding Calvin and Bucer, has 
carefully investigated the relations of the Heidelberg Catechism, to antecedent compendiums of a similar [16] character which the Reformation produced in his Der Heidelberger Katechismus und Vier Verwandte Katechismen (Leipzig, 1907).

English Church History has been enriched by W. H. Frere and C. E. Douglas through their Puritan Manifestoes: A Study of the Origin of the Puritan Revolt (London, 1907). The first named author is the well-known reviser of Procter's History of the Book of Common Prayer. This volume makes accessible many of the rarer Puritan tracts and renders it possible to form a more accurate judgment as to the origin and early history of the Puritan movement than heretofore. Mr. Champlin Burrage, a young American scholar, who holds the Research Fellowship of Newton Theological Institution, has continued his investigations of the history and writings of Robert Browne, the father of Congregationalism, which have already resulted in the discovery of much fresh material and several treatises supposedly lost. In the Lambeth Library, he has found a tract of 1588 from Browne's pen, which he has published as The Retraction of Robert Browne (Oxford, 1907), and which reveals that vigorous controversialist in a surprisingly sane, mild, and reasonable frame of mind, and may be said practically to refute the contention of the late Rev. Dr. Dexter, based on much less knowledge of the sources, that Browne was mentally unbalanced, in consequence of his sufferings, when he made his peace with the Church of England. The year has witnessed the completion of the English scholar, R. W. Dale's elaborate History of English Congregationalism by his son, A. W. W. Dale (A History of English Congregationalism, London, 1907), offering, in one thick volume, a full and scholarly discussion of the history of this religious body in the land of its origin from its beginnings to the present. Of less significance, but still a valuable compendium, covering a most eventful period, is Alfred Plummer's English Ckurch 


\section{The Current Outlook in Church History}

History from the Death of Charles I to the Death of William III (Edinburgh, 1907).

Mention should be made of a new German series of much promise, under the editorship of $\mathrm{H}$. Hoffmann and $\mathrm{L}$. Zscharnack, entitled Studien zur Geschichte des neueren Protestantismus [17] (Giessen, 1907), in which a number of valuable discussions have been issued during the year. Another discussion of modern Church History is that of an eminent American scholar, Dr. Frank H. Foster, entitled, $A$ Genetic History of the New England Theology (Chicago, 1907). In acquaintance with the leaders of New England thought and their relations one to another, and in keenness of critical estimate as to their relative value and the significance of their services to Christian theology, this work of Dr. Foster's is easily the superior of anything that has yet been written upon this theme. Less fresh in its contributions and rather to be considered as a compendious sketch, is T. Hughes's History of the Sociely of Jesus in North America (London, 1907). Mr. George H. Putnam, the well-known publisher, has completed his Censorship of the Church of Rome and its Influence upon the Production and Distribution of Literaturethe second volume, treating especially of the last century, having been published this year (New York, 1907). Mr. Putnam's work is very largely a compilation, but it has made accessible in English much that has heretofore not been available to the reader whose knowledge was confined to that language. Prof. Henry C. Sheldon of Boston University has published a useful history of Unbelief in the Nineteenth Century (New York, 1907); and an English rector, Arthur Galton, Vicar of Edenham, has issued a particularly timely survey of Church and State in France, 1300 to 1907 (London, 1907), of special service through its discussions of the recent relations of Church and State in that land.

Our consideration of this list of publications, which in spite of a length that I fear has already wearied you, cannot be regarded as exhaustive but simply as giving the more sig- 
nificant, leaves us no cause to be ashamed of American scholarship. The discussions of the past year from the pens of students on this side of the Atlantic, have covered a wide range of topics in the great field of Church History, and are such as [18] to hold an honorable place in the contributions which have been made during the period to the studies which this Society regards as of prime importance. Certainly, we have abundant reason to feel that Church History is commanding, year by year, a wider attention and a more profound study from American scholars. In examining their work for the year, however, we must have been impressed with the fact that there is, as yet, little evidence of coöperation in effort on this side of the Atlantic. Individual studies of great importance and thoroughness, like those of Mr. Lea, President Hartranft, and Dr. Foster, to mention no others, have been begun or brought to successful completion and are an honor to American learning, but there is as yet little united effort on the part of American scholars, and their discussions are controlled by no systematic attempts, such as we see in France and Germany, to examine by collective endeavor distinct fields of history of which they may take, if not exclusive, yet prime possession. It should be the object of a Society like this to promote such acquaintance and cooperation between American scholars and thus to aid the study of Church History at the point at which it now seems most deficient in this country. One field in particular should be our especial province; it is that of American Church History. The services of this Society, initiated by the late Prof. Schaff, and resulting in the "American Church History Series," have given us the inestimable benefit of careful denominational histories. But we need to go a step further. A thorough examination of the history of Christianity as a whole in the United States, such as was foreshadowed, though necessarily in a very limited way, by our late colleague, Rev. Dr. Leonard W. Bacon, in the thirteenth volume of the Series just mentioned, is a desideratum. It 


\section{The Current Outlook in Church History}

might be well undertaken under the auspices of this Society; which would thus garner and present in a form that would command foreign recognition, as well as serve American scholars, the significant contributions of American Christianity as a whole to the history of the Christian church. The religious life on this side the Atlantic has, indeed, its sources beyond the sea, and its history reflects much of the discussions which have run their course on European [I9] soil; but it has, nevertheless, its own flavor, and has made conspicuous contributions to Christianity as a whole, and these deserve an adequate treatment, such as they cannot have under the limitations of denominational discussion, but such as easily might be given to them in a general history of American Christianity. Such a work might fittingly be inaugurated under the auspices of the American Society of Church History. 